\title{
The Adverse Prognostic Hallmarks in Identical Twins with Langerhans Cell Histiocytosis: A Clinical Report and Literature Review
}

\author{
Damin Chai, ${ }^{1,2}$ Yisheng Tao, ${ }^{1}$ Zhengqi Bao,${ }^{3}$ Li Yang, ${ }^{4}$ Zhenzhong Feng, ${ }^{1}$ Li Ma, ${ }^{1}$ \\ Limei Liang ${ }^{5}$ and Xinwen Zhou $^{2}$ \\ ${ }^{1}$ Department of Pathology, 1st Affiliated Hospital, Bengbu Medical College, Bengbu, Anhui, P.R. China \\ ${ }^{2}$ Department of Pathophysiology, Tongji Medical College, Huazhong University of Science and Technology, \\ Wuhan, Hubei, P.R. China \\ ${ }^{3}$ Department of Orthopedics, 1st Affiliated Hospital, Bengbu Medical College, Bengbu, Anhui, P.R. China \\ ${ }^{4}$ Department of Radiology, 1st Affiliated Hospital, Bengbu Medical College, Bengbu, Anhui, P.R. China \\ ${ }^{5}$ Department of Obstetrics and Gynaecology, 1st Affiliated Hospital, Bengbu Medical College, Bengbu, Anhui, \\ P.R. China
}

Langerhans cell histiocytosis $(\mathrm{LCH})$ is characterized by uncontrolled proliferation of Langerhans cells accompanying eosinophils. It often attacks children under 10 years of age. $\mathrm{LCH}$ in identical twins is very rare and its prognosis is different. Here we report identical-twin sisters with LCH. Computed tomography (CT) revealed osteolytic change in each twin's skull, and the elder exhibited poor eyesight. There were massive histiocyte-like cells surrounded by eosinophils in pathologic specimen of the abnormal lesions, which is typical pathologic finding in LCH. These pathologic cells were positive for $\mathrm{S}-100$ and the cell surface protein CD1 antigen (CD1 $\alpha$ ), the known markers of LCH. After treating them with surgery, no symptoms were seen in the younger until now. While the older was found another soft mass (about $2.0 \mathrm{~cm}$ in diameter) in the left temporal area 18 months later. The same treatment was given to the older after admission, and she is healthy to date. To explore the relationship between hallmarks and the prognosis of identical-twin patients with $\mathrm{LCH}$, we retrieved the 16 literatures (16 identical-twin pairs, 31 patients) listed in PubMed during the past 60 years. The data revealed all those patients who have disseminated to the bone marrow, spleen and liver with symptoms of fever and hepatosplenomegaly exhibited worse prognosis ( 9 out of the 31 patients). The other identical-twin subjects without infiltration of those organs recovered well. In conclusion, this study reveals the adverse hallmarks of prognosis in identical-twin patients with LCH by reviewing relevant literatures.

Keywords: hallmarks; identical twins; Langerhans cell histiocytosis; prognosis; risk organs

Tohoku J. Exp. Med., 2013 August, 230 (4), 219-225. C 2013 Tohoku University Medical Press

\section{Introduction}

Langerhans cell histiocytosis (LCH) is characterized by uncontrolled proliferation of Langerhans cells accompanying eosinophils (Haupt et al. 2013). Also known as Langerhans cell granulomatosis or histiocytosis $\mathrm{X}$, it is an idiopathic, monoclonal disease that primarily attacks children under 10 years old. The incidence of LCH is approximately 3 to 5 children in a population of 100,000 . LCH in identical twins is very rare and the clinical characteristics are different. During the past 60 years, only 16 identicaltwin pair patients (16 literatures) with LCH have been reported in PubMed since Lightwood and Tizard (1954) first reported the brothers with LCH (Bierman 1966;
Caldarini 1966; Juberg et al. 1970; Jakobson et al. 1987; Kuwabara and Takahashi 1990; Katz et al. 1991; Enjolras et al. 1992; Halton et al. 1992; Kanold et al. 1994; Mader et al. 1996; Dufour et al. 2001; Patel and Renge 2001; Chen et al. 2004; Imai et al. 2010; Fernandez-Torres et al. 2011). A high $(86 \%)$ concordance rate for LCH in twins is identical, but is not dizygotic (Arico and Danesino 2001).

Here we report identical-twin sisters with LCH diagnosed at our hospital (1st Affiliated Hospital of Bengbu Medical College), with the approval (prior to the start of the research project) of their parents and the Ethical Committee of Bengbu Medical College. To our knowledge, the characteristics and the relationship between hallmarks and prognosis of patients with $\mathrm{LCH}$ in identical twins have not been

Received January 15, 2013; revised and accepted July 22, 2013. Published online August 7, 2013; doi: 10.1620/tjem.230.219.

Correspondence: Xinwen Zhou, Department of Pathophysiology, Tongji Medical College, Huazhong University of Science and Technology, Wuhan 430030, P.R.China.

e-mail: zhouxinwen@mail.hust.edu.cn 
reported in detail until now. In this report, we will also explore the hallmarks affecting prognosis of identical-twin patients with $\mathrm{LCH}$ by reviewing the 16 literatures reported to date. Patients were assessed according to age of onset, disease extent, symptoms, therapy and follow-up out-come.

\section{Clinic Report}

The identical-twin sisters, determined by the simple tandem repeat polymorphism (SNP), were born by abdominal delivery (Table 1). The general characteristics of the identical-twins' parents were as follows: the father, age 32, and the mother, age 28, are Chinese, in good health, and of normal intelligence. Twin 1 is the elder sister, $3.2 \mathrm{~kg}$ at birth, while Twin 2 is the younger, $3.1 \mathrm{~kg}$ at birth. The mother showed no signs of infection with any virus or bacteria during pregnancy. The twins were bottle-fed and were vaccinated regularly and on time. Their growth progress was typical of other children of the same age. The twins have a healthy younger brother. Family and medical history of the twins was unremarkable until symptoms of $\mathrm{LCH}$ appeared.

\section{Twin 1}

Symptoms: In June, 2010, when she was 14 months, the elder sister was found to have a soft, non-tender mass in the right temporal area approximately $2.0 \mathrm{~cm}$ in diameter. After about seven months' observation, the mass had enlarged and her eyesight worsened as the girl matured. Hair dense in the area of the mass was less than that in the surrounding scalp. Twin 1 was admitted to the First Affiliated Hospital of Bengbu Medical College in January 2011.

Table 1. Results of the simple tandem repeat polymorphism of the identical-twin sisters.

\begin{tabular}{lcc}
\hline \multicolumn{1}{c}{ Variable } & Twin 1 & Twin 2 \\
\hline D8S1179 & $10 / 14$ & $10 / 14$ \\
D21S11 & 29 & 29 \\
D7S820 & $9 / 11$ & $9 / 11$ \\
CSF1PO & $12 / 13$ & $12 / 13$ \\
D3S1358 & 15 & 15 \\
TH01 & $6 / 9$ & $6 / 9$ \\
D13S317 & 8 & 8 \\
D16S539 & $9 / 10$ & $9 / 10$ \\
D2S1338 & $19 / 23$ & $19 / 23$ \\
D19S433 & $13 / 16$ & $13 / 16$ \\
vWA & $14 / 18$ & $14 / 18$ \\
TPOX & $8 / 11$ & $8 / 11$ \\
D18S51 & $13 / 14$ & $13 / 14$ \\
D5S818 & $10 / 11$ & $10 / 11$ \\
FGA & 24 & 24 \\
Amel & $\mathrm{X} / \mathrm{X}$ & $\mathrm{X} / \mathrm{X}$ \\
\hline
\end{tabular}

Test with the identical-twin sisters' blood specimen by an identifilier plus kit (AB Company, USA)
Clinical examination findings: On examination and palpation, an immobile mass approximately $4.0 \mathrm{~cm}$ in diameter was discovered in the right temporal area. Cranial computed tomography (CT) scanning disclosed an ovalshaped mass $4.9 \times 3.2 \times 3.0 \mathrm{~cm}$ in size. The mass had invaded into the inner eye region of the right eye circular muscle and external rectus muscle. The right eyeball was extruded (Fig. 1A) and the invasive mass reached the outer region of the corresponding right skull (osteolytic change was found) (Fig. 1B).

Lab findings: The platelets were significantly reduced, and other lab findings, such as hemoglobin and inflammatory cells, had no notable changes when she first visited our hospital (Table 2).

Treatment: Surgery was performed on Twin 1. During surgery $10.0 \mathrm{ml}$ of fuscous blood effused from the mass, which was tightly bound to the right eye circular muscle and external rectus muscle. The extent of invasion into the skull in the right temporal area was approximately $3.0 \times 4.0$ $\times 5.0 \mathrm{~cm}$ in size and a capsule approximately $3.5 \mathrm{~cm}$ in diameter was discovered among striated muscle (Fig. 2A). Treated with potassium sodium dehydroandroan drographolide succinate, cefotiam and ribavirin to prevent inflammation during the extended duration of the operation (more than three hours), she recovered and her poor eyesight gradually improved (Table 3 ).

Pathologic findings: Subsequent analysis of the pathological specimen from the abnormal lesions fixed in $10 \%$ neutral buffered formalin (NBF), processed into paraffin blocks, sectioned, and stained with routine hematoxylin eosin (HE) showed features of LCH. Massive histiocytelike cells, which had irregularly contoured or folded nuclei, were infiltrated with eosinophils in the lesions (Fig. 2B). After decalcification to make pathology slices clearly by exorcizing calcium salt of bone, numerous histiocyte-like cells (pathologic Langerhans cells) were found among cranial bone trabeculae (Fig. 2C). Immunohistochemical staining showed that these pathologic Langerhans cells were positive for S-100 protein, the cell surface protein CD1 antigen (CD1 $\alpha$ ) (Fig. 2D and E), CD68 and lysozyme (data not shown). These proteins are the known markers of LCH diagnosis (Margo and Goldman 2008). The labeling index of Ki-67, which is a marker of proliferation of the pathologic cells, was about $25 \%$ (Fig. 2F). The anti-S-100 protein, anti-CD1 $\alpha$ and anti-CD68 antibodies used were obtained from Abcam Technology (Cambridge Science Park, Cambridge, UK), and anti-lysozyme and anti-Ki-67 antibodies from Santa Cruz Biotechnology (Santa Cruz, CA).

Follow-up: In July 2012, about 18 months after the surgery, another soft mass measuring approximately $2.0 \mathrm{~cm}$ in diameter was found in the left temporal area (Fig. 1C). Twin 1 was treated with penicillin and cephalosporin, but after therapy over a two-month period, the size of the tumor was little changed (Fig. 1D). Treatment will be given to her by other method (Table 3). 

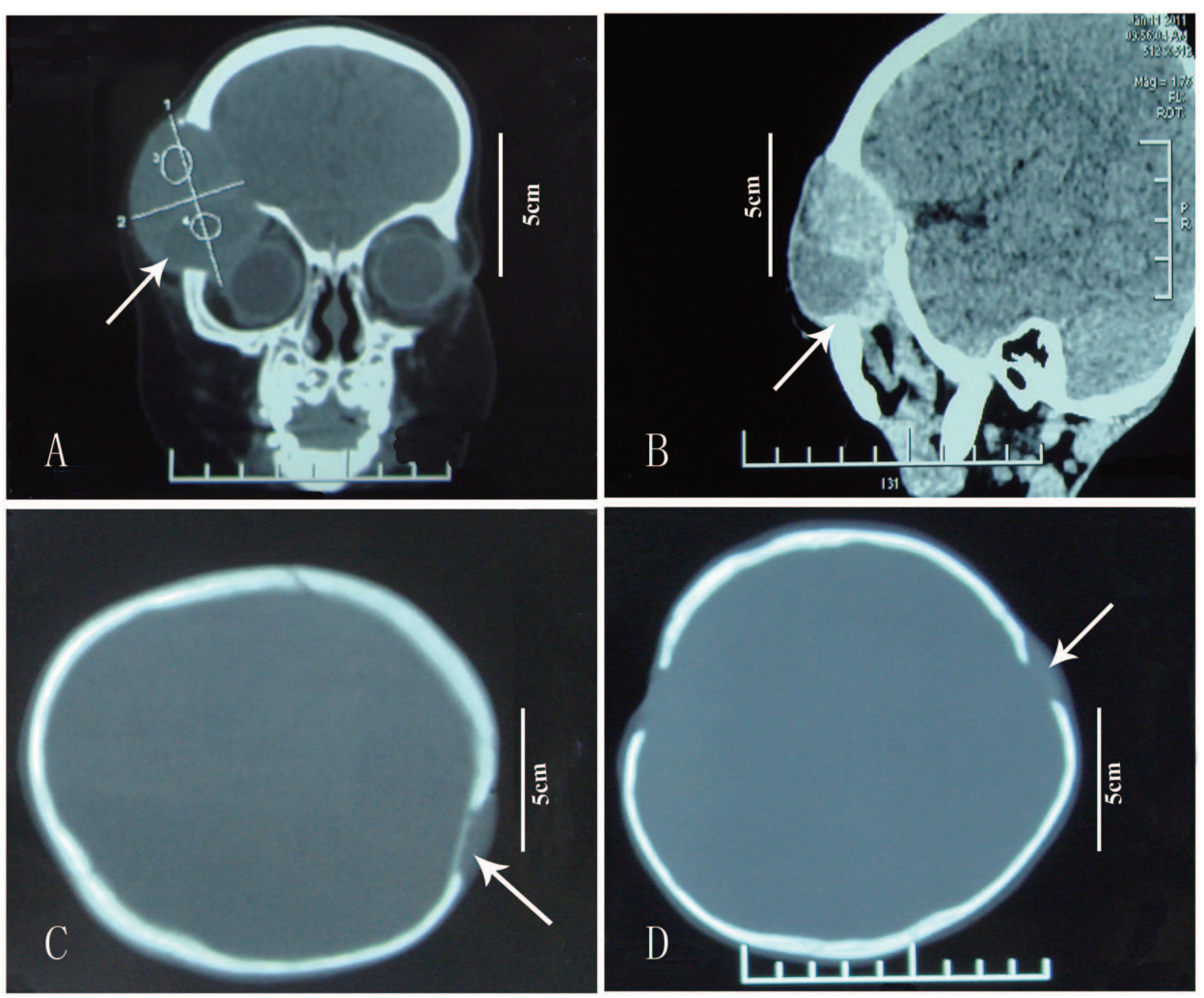

Fig. 1. Cranial computed tomography (CT) images of Twin 1 .

A, B. The mass invaded the circular muscle and external rectus muscle of the right eye and dissolved skull (January,

2011). C. Another mass dissolved skull in the left temporal area approximately $2.0 \mathrm{~cm}$ in diameter (July, 2012).

D. Another mass changed little when treated with antibiotics in the left temporal area (November, 2012).

Twin 2

Symptoms: In June 2010, at the age of 18 months, the younger of the twins was also determined to have a soft, non-tender mass about $4.0 \mathrm{~cm}$ in diameter in the left copula and pulvinar conjunctive part near the neutral line. During 4 months of observation, the mass enlarged gradually to 5.5 $\times 5.0 \times 2.5 \mathrm{~cm}$ as measured in April 2011 using CT (Fig. 3).

Clinical examination findings: The round-shape mass did not pulsate, but penetrated the outer skull to the scalp, destroying some skull bones before grew inward and becoming intermingled with brain tissue.

Lab findings: There were no significant abnormal laboratory findings or notable changes when she first visited our hospital (Table 2).

Treatment: The mass was surgically excised and treated with medication and protocols similar to those used for Twin 1.

Pathologic findings: The analysis procedure was the same as that followed with Twin 1. By HE staining, the pathologic Langerhans cells that had irregularly contoured or folded nuclei, were surrounded by eosinophils, monocyte and hemosiderin, which was similar as Twin 1 (Fig. 4A). Immunohistochemical staining showed that these cells were positive for S-100 protein (Fig. 4B) and CD1 $\alpha$ (Fig. 4C), but negative for CD68 or lysozyme (data not shown). The labeling index of Ki-67 of the pathologic cells was more than $50 \%$ (Fig. 4D).

Follow-up: To date of writing this report, Twin 2 has been free of symptoms for 20 months (Table 3).

\section{Discussion}

$\mathrm{LCH}$ itself is rare and rarer still in identical twins. There were only 16 identical-twin pairs suffered from $\mathrm{LCH}$ during the past sixty years. Here we report Twin 1 and Twin 2 described in the Case Report above. The characteristics and prognosis of LCH in identical twins are not well understood. Arico and colleagues (1999) suggested that LCH was not hereditary or familial. However, BadalianVery et al. (2012) found that the activating mutation BRAF V600E appeared in $57 \%$ of those patients with $\mathrm{LCH}$, which indicated that the role of heredity in onset of the disease is open to dispute, though the mutation is not correlated with the severity of the disease. Treatment with IFN- $\alpha$ was effective and well tolerated in identical-twin patients with LCH, suggesting that immunological abnormality may also have a role in identical-twin pair with LCH (Jakobson et al. 1987). We are inclined to agree that genetic factors may be an important causal agent of identical twins with LCH.

Although the presentations in identical-twin pairs and in sporadic patients with LCH are quite disparate, the proliferating pathologic Langerhans cells share similar morphologies and molecular markers (Arico et al. 1999; 
Table 2. Result of laboratory investigation of the identical-twin sisters.

\begin{tabular}{|c|c|c|c|c|}
\hline & Variable & Twin 1 & Twin 2 & Reference range \\
\hline \multirow{10}{*}{ Blood cell data } & Leucocyte $\left(10^{9} / 1\right)$ & 8.75 & 11.94 & $5.0-10.0$ \\
\hline & Neutrophils $\left(10^{9} 9 / 1\right)$ & 3.31 & 10.67 & $2.0-7.5$ \\
\hline & Lymphocyte $\left(10^{9} / 1\right)$ & 4.32 & 1.04 & $0.3-4.0$ \\
\hline & Eosinophil $\left(10^{9} / 1\right)$ & 0.40 & 0.01 & $0.02-0.5$ \\
\hline & Basophil $\left(10^{9} / 1\right)$ & 0.01 & 0.00 & $0-0.1$ \\
\hline & Monocyte $\left(10^{9} / 1\right)$ & 0.71 & 0.20 & $0.08-0.9$ \\
\hline & $\mathrm{RBC}\left(\times 10^{12} / \mathrm{L}\right)$ & 4.7 & 3.9 & $4.0-4.5$ \\
\hline & Hemoglobin (g/L) & 117 & 99 & $120-140$ \\
\hline & MV-RBC (F1) & 80.4 & 77.9 & $82.6-99.1$ \\
\hline & Platelet $\left(\times 10^{9} / \mathrm{L}\right)$ & 11 & 15 & $100-300$ \\
\hline \multirow{8}{*}{ Biochemical data } & $\operatorname{ALT}(\mathrm{u} / \mathrm{L})$ & 16 & 11 & $5-35$ \\
\hline & $\operatorname{AST}(u / L)$ & 44 & 39 & $5-40$ \\
\hline & Prealbumin (mg/L) & 215 & 177 & $100-200$ \\
\hline & $\mathrm{TCO}_{2}(\mathrm{mmol} / \mathrm{L})$ & 21.8 & 23.4 & $22-29$ \\
\hline & $\mathrm{AG}(\mathrm{m} \mathrm{mol} / \mathrm{L})$ & 17.2 & 10.4 & $8-16$ \\
\hline & $\mathrm{PT}(\mathrm{s})$ & 10.4 & 10.9 & $11-15$ \\
\hline & Fibrinogen $(\mathrm{g} / \mathrm{L})$ & 1.7 & 3.7 & $2-4$ \\
\hline & CRP & 10.2 & 18.68 & $0-6$ \\
\hline \multirow[t]{4}{*}{ Blood type } & $\mathrm{ABO}$ positive stereotypy & $\mathrm{O}$ & $\mathrm{O}$ & \\
\hline & ABO negative stereotypy & $\mathrm{O}$ & $\mathrm{O}$ & \\
\hline & Rho(D) & Positive & Positive & Positive \\
\hline & Irregular antibody screen & Negative & Negative & Negative \\
\hline
\end{tabular}

AG, anion gap; ALT, alanine aminotransferase; AST, aspartate aminotransferase; CRP, C reactive protein; MV-RBC, mean volume of RBC; PT, prothrombin time; $\mathrm{RBC}$, red blood cell; $\mathrm{TCO}_{2}$, total Carbon Dioxide.
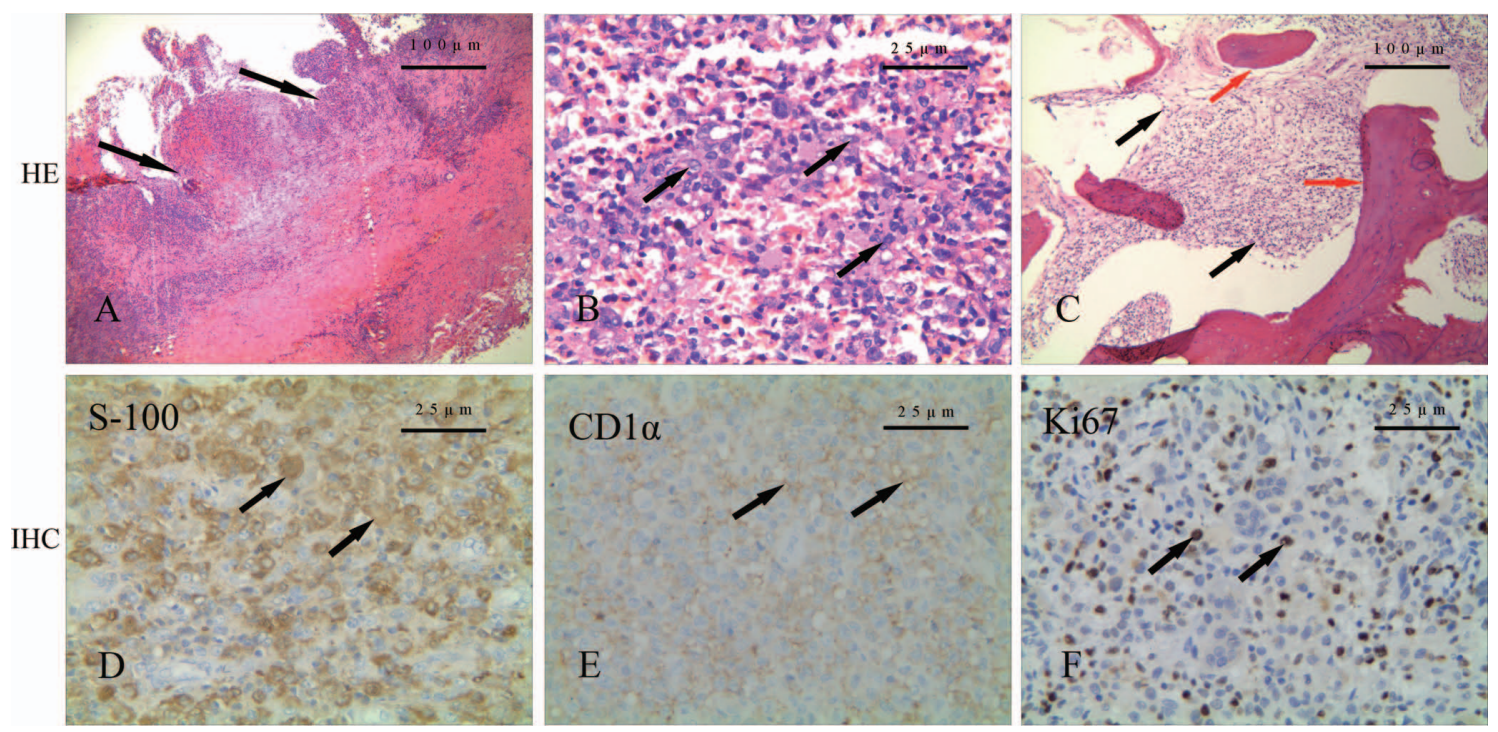

Fig. 2. Hematoxylin eosin (HE) and immunohistochemical staining of Twin 1.

A. A capsule approximately $3.5 \mathrm{~cm}$ in diameter surrounded by striated muscle by HE staining (black arrow is capsule wall constructed by striated muscle). B. Toward the center of the pathologic Langerhans cell's abundant cytoplasm there is a folded nucleus with prominent nuclear membrane and nucleolus (black arrow is pathologic Langerhans cell). C. Pathologic Langerhans cells were found among skull after decalcification by HE staining (black arrow is pathologic Langerhans cell, red arrow is bone trabeculae). D. Positive immunohistochemical staining of S-100 protein of pathologic Langerhans cells (black arrow is pathologic Langerhans cell). E. Positive immunohistochemical staining of cell surface protein $\mathrm{CD} 1$ antigen $(\mathrm{CD} 1 \alpha)$ (black arrow is pathologic Langerhans cell). F. Positive immunohistochemical staining of Ki-67 of pathologic Langerhans cells' nucleolus (black arrow is pathologic Langerhans cell). 
Table 3. Clinical information and prognosis of the identical-twin sisters.

\begin{tabular}{|c|c|c|}
\hline Variable & Twin 1 & Twin 2 \\
\hline Age at diagnosis & 14 months & 18 months \\
\hline Macrophage activation syndrome & No & No \\
\hline Symptom & $\begin{array}{l}\text { Subcutaneous mass, } \\
\text { poor eyesight }\end{array}$ & Subcutaneous mass \\
\hline Extension at the time of diagnosis & $\begin{array}{l}\text { A mass about } 2.0 \mathrm{~cm} \text { in diameter in the right } \\
\text { temporal area }\end{array}$ & $\begin{array}{l}\text { A mass about } 4.0 \mathrm{~cm} \text { in the diameter in left } \\
\text { copula and pulvinar conjunctive part near } \\
\text { the neutral line }\end{array}$ \\
\hline Extension of the maximal extend & $\begin{array}{l}\text { The mass about } 4.9 \mathrm{~cm} \text { in diameter and } \\
\text { osteolytic change was found }\end{array}$ & $\begin{array}{l}\text { The mass about } 5.5 \mathrm{~cm} \text { in diameter and } \\
\text { osteolytic change was found }\end{array}$ \\
\hline Therapy & Resection and antibiotic therapy & Resection and antibiotic therapy \\
\hline Follow up period & 24 months & 20 months \\
\hline Response to therapy & Well & Well \\
\hline Reactivation with delay from diagnosis & $\begin{array}{l}\text { About } 18 \text { months after the surgery another } \\
\text { mass about } 2.0 \mathrm{~cm} \text { in diameter was found in } \\
\text { the left temporal area }\end{array}$ & No other lesion was found \\
\hline Sequels & $\begin{array}{l}\text { Dehydroandroan drographolide succinate, } \\
\text { cefotiam and ribavirin }\end{array}$ & $\begin{array}{l}\text { Dehydroandroan drographolide succinate, } \\
\text { cefotiam and ribavirin }\end{array}$ \\
\hline
\end{tabular}

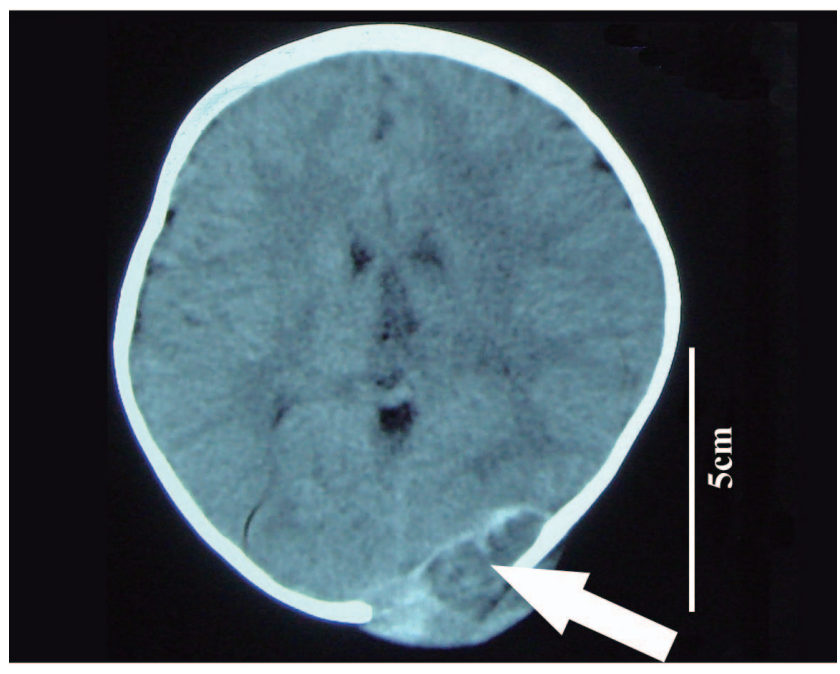

Fig. 3. Cranial computed tomography (CT) image of Twin 2. A mass in the left copula and pulvinar conjunctive part near the neutral line (arrow is the mass which dissolved the skull).

Badalian-Very et al. 2012). Toward the center of the cytoplasm there is a folded nucleus with a prominent nuclear membrane and nucleoli. The pathologic Langerhans cells have an affinity for S-100 protein, making it a useful aid in histological diagnosis (Margo and Goldman 2008). In the present report, the marker of S-100 protein was also positive (Fig. 2D and 4B). Unlike S-100 protein, which is found on the surface of a wide variety of cell types, CD1 $\alpha$ is highly specific for Langerhans cells and is the most important marker of LCH for Langerhans cells expressing CD1 $\alpha$ (Margo and Goldman 2008). In the case of our twins, the cells of $\mathrm{LCH}$ in both patients express $\mathrm{CD} 1 \alpha$ (Fig. $2 \mathrm{E}$ and $4 \mathrm{C}$ ). However, it should be noted that pathologic Langerhans cells of the twins showed different reactions to
anti-CD68 and anti-lysozyme antibodies, despite that CD68 and lysozyme are markers of LCH.

The characteristic biological behavior of identical-twin pair with LCH is more like a tumor encompassing heterogeneous clinical manifestations and prognosis, according to the literature. All the identical-twin patients with LCH were children 0-4 years old with the exception of one adult pair. Among the 17 identical sets of twins with $\mathrm{LCH}$ including Twin 1 and Twin 2 reported here, 11 pairs were males (64.71\%) and 6 were females (33.29\%) (Bierman 1966; Caldarini 1966; Juberg et al. 1970; Jakobson et al. 1987; Kuwabara and Takahashi 1990; Katz et al. 1991; Enjolras et al. 1992; Halton et al. 1992; Kanold et al. 1994; Mader et al. 1996; Dufour et al. 2001; Patel and Renge 2001; Chen et al. 2004; Imai et al. 2010; Fernandez-Torres et al. 2011). The most frequently affected organs were bone and skin, followed by lymph node and ear, with the next being bone marrow, liver, spleen and lung. Most of the identical-twin pair patients with LCH sought medical treatment because of a certain combination of pain, swelling, skin rashes, otorrhea, fever, diarrhea, poor weight gain, growth failure, respiratory symptoms, irritability, neurological changes and impaired vision.

To grasp the hallmarks affecting the prognosis of identical-twin pairs with $\mathrm{LCH}$, the relationship between followup outcome and parameters noted earlier in identical-twin patients were analyzed. The data revealed that all of the 5 identical-twin pair cases with LCH (a total of 9 patients, only one child of one pair in the 5 pairs was involved) died as a result of disseminated and infiltrated lesions to the bone marrow, spleen and liver with symptoms of fever and hepatosplenomegaly (Juberg et al. 1970; Katz et al. 1991; Enjolras et al. 1992; Halton et al. 1992; Fernandez-Torres et al. 2011). Conversely, the other patients, who were not infiltrated to these risk organs, had a better prognosis, even 

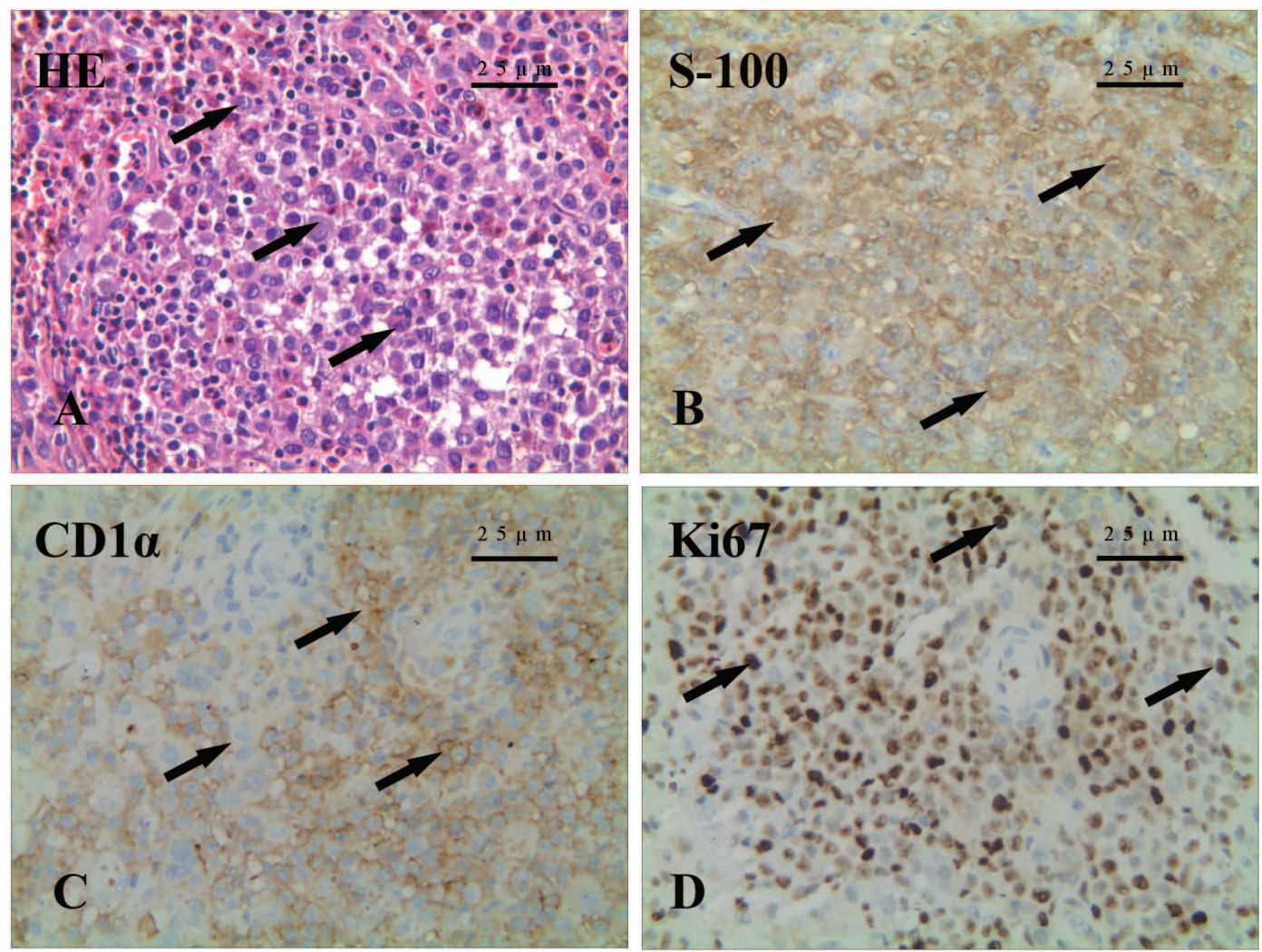

Fig. 4. Hematoxylin eosin and immunohistochemical staining of Twin 2.

A. Hematoxylin eosin (HE) staining of pathologic Langerhans cells. B. The pathologic Langerhans cells positive staining of S-100 protein. C. The pathologic Langerhans cells positive staining of cell surface protein CD1 antigen (CD1 $\alpha)$. D. The pathologic Langerhans cells positive staining of Ki-67 (B, C, D is immunohistochemical staining, arrow is pathologic Langerhans cell in all figures).

though those patients' multiple bone, the skin, lymph nodes, ear and lung were infiltrated by pathologic Langerhans cells (Lightwood and Tizard 1954; Bierman 1966; Caldarini 1966; Jakobson et al. 1987; Kuwabara and Takahashi 1990; Kanold et al. 1994; Mader et al. 1996; Dufour et al. 2001; Patel and Renge 2001; Chen et al. 2004; Imai et al. 2010). The twin sisters reported here currently undergoing treatment at our hospital had not experienced dissemination to the risk organs to date and recovered well. The relationship between follow-up outcome and parameters suggests that the prognosis of identical-twin pair patients with primary LCH is ultimately determined by infiltration of the risk organs.

In conclusion, analyzing the identical-twin patients with $\mathrm{LCH}$ and reviewing relevant literatures of identicaltwin patients with $\mathrm{LCH}$, we show the adverse hallmarks of prognosis, dissemination to the bone marrow, spleen and liver, which ultimately results in death. For understanding the disease and determining the best course of treatment, the underlying molecular mechanisms of twin pair patients diagnosed with LCH should be explored in future research.

\section{Grants}

This work was supported in part by the Natural Science Research Program of Education Bureau of Anhui Province (NO.
KJ2011A203), the Medicine Sciences Program of Bengbu Technology Bureau (NO. 20120317).

\section{Acknowledgements}

The authors would like to thank an American friend for his critical review of the English usage in the manuscript and Professor Zhiwen Jiang for his help in translating the French references.

\section{Conflict of Interest}

The authors declare no conflict of interest.

\section{References}

Arico, M. \& Danesino, C. (2001) Langerhans' cell histiocytosis: is there a role for genetics? Haematologica, 86, 1009-1014.

Arico, M., Nichols, K., Whitlock, J.A., Arceci, R., Haupt, R., Mittler, U., Kuhne, T., Lombardi, A., Ishii, E., Egeler, R.M. \& Danesino, C. (1999) Familial clustering of Langerhans cell histiocytosis. Br. J. Haematol., 107, 883-888.

Badalian-Very, G., Vergilio, J.A., Degar, B.A., Rodriguez, G.C. \& Rollins, B.J. (2012) Recent advances in the understanding of Langerhans cell histiocytosis. Br. J. Haematol., 156, 163-172.

Bierman, H.R. (1966) Apparent cure of Letterer-Siwe disease. Seventeen-year survival of identical twins with nonlipoid reticuloendotheliosis. JAMA, 196, 368-370.

Caldarini, G. (1966) Remarks on a case of Letterer-Siwe disease in a pair of twins. Clin. Pediatr. (Bologna), 48, 315-332.

Chen, C.J., Ho, T.Y., Lu, J.J., Sheu, L.F., Lee, S.Y., Tien, C.H. \& 
Chen, S.N. (2004) Identical twin brothers concordant for Langerhans' cell histiocytosis and discordant for Epstein-Barr virus-associated haemophagocytic syndrome. Eur. J. Pediatr., 163, 536-539.

Dufour, C., Lanciotti, M., Micalizzi, C., Valetto, A. \& Haupt, R. (2001) Non-identical twin sisters concordant for Langerhans cell histiocytosis and discordant for secondary acute promyelocytic leukemia. Med. Pediatr. Oncol., 37, 70-72.

Enjolras, O., Leibowitch, M., Bonacini, F., Vacher-Lavenu, M.C. \& Escande, J.P. (1992) Congenital cutaneous Langerhans histiocytosis. Apropos of 7 cases. Ann. Dermatol. Venereol., 119, 111-117.

Fernandez-Torres, R., Granero, E., Paradela, S. \& Fonseca, E. (2011) Congenital Langerhans cell histiocytosis involving only one of non-identical twins. Eur. J. Dermatol., 21, 457-458.

Halton, J., Whitton, A., Wiernikowski, J. \& Barr, R.D. (1992) Disseminated Langerhans cell histiocytosis in identical twins unresponsive to recombinant human alpha-interferon and total body irradiation. Am. J. Pediatr. Hematol. Oncol., 14, 269-272.

Haupt, R., Minkov, M., Astigarraga, I., Schafer, E., Nanduri, V., Jubran, R., Egeler, R.M., Janka, G., Micic, D., RodriguezGalindo, C., Van Gool, S., Visser, J., Weitzman, S. \& Donadieu, J. (2013) Langerhans cell histiocytosis (LCH): guidelines for diagnosis, clinical work-up, and treatment for patients till the age of 18 years. Pediatr. Blood Cancer, 60, 175-184.

Imai, K., Matsumoto, N., Sakamoto, A., Yanagi, S., Ashitani, J. \&
Nakazato, M. (2010) Pulmonary Langerhans cell histiocytosis in identical twins. Nihon Kokyuki Gakkai Zasshi, 48, 502-505.

Jakobson, A.M., Kreuger, A., Hagberg, H. \& Sundstrom, C. (1987) Treatment of Langerhans cell histiocytosis with alpha-interferon. Lancet, 2, 1520-1521.

Juberg, R.C., Kloepfer, H.W. \& Oberman, H.A. (1970) Genetic determination of acute disseminated histiocytosis X. Pediatrics, 45, 753-765.

Kanold, J., Vannier, J.P., Fusade, T., Drouin, V., Thomine, E., Prudent, M. \& Tron, P. (1994) Langerhans-cell histiocytosis in twin sisters. Arch. Pediatr., 1, 49-53.

Katz, A.M., Rosenthal, D., Jakubovic, H.R., Pai, R.K., Quinonez, G.E. \& Sauder, D.N. (1991) Langerhans cell histiocytosis in monozygotic twins. J. Am. Acad. Dermatol., 24, 32-37.

Kuwabara, S. \& Takahashi, M. (1990) Eosinophilic granuloma of the skull in identical twins - case report. Neurol. Med. Chir. (Tokyo), 30, 1043-1046.

Lightwood, R. \& Tizard, J.P. (1954) Recovery from acute infantile non-lipoid reticuloendotheliosis (Letterer-Siwe disease). Acta Paediatr. Suppl., 43, 453-468.

Mader, I., Stock, K.W., Radue, E.W. \& Steinbrich, W. (1996) Langerhans cell histiocytosis in monocygote twins: case reports. Neuroradiology, 38, 163-165.

Margo, C.E. \& Goldman, D.R. (2008) Langerhans cell histiocytosis. Surv. Ophthalmol., 53, 332-358.

Patel, A.B. \& Renge, R.L. (2001) Langherhans cell histiocytosis in monozygotic twins. Indian Pediatr., 38, 788-791. 